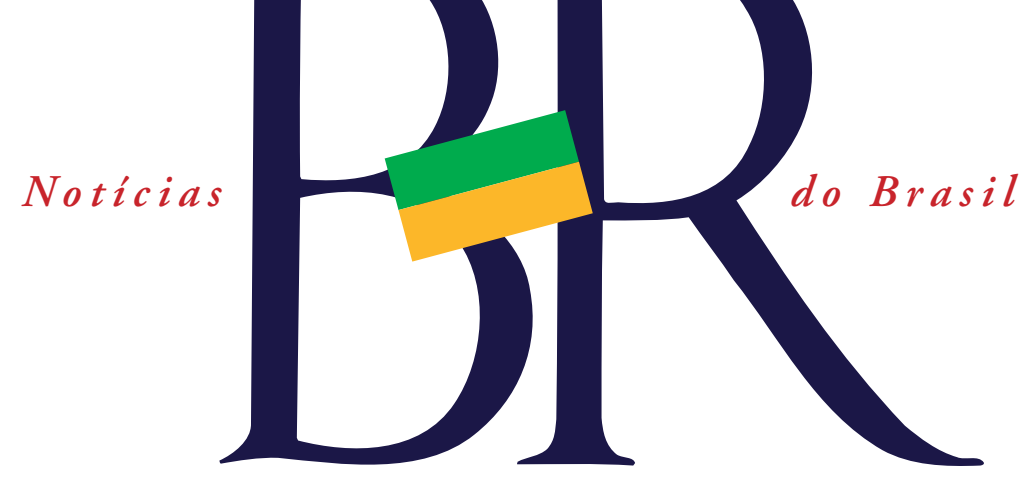

Ciência e Tecnologia

\section{0 acelerador Sirius: governo investe em tecnologia de ponta}

Localizada na cidade de Campinas, está a única fonte de luz síncrotron da América do Sul. O Laboratório Nacional de Luz Síncrotron (LNLS) funciona como um laboratório multiusuário, de portas abertas à comunidade acadêmica e empresarial do Brasil e do exterior. Ele opera sob a gestão do Centro Nacional de Pesquisa em Energia e Materiais (CNPEM). Há alguns anos, o LNLS tem trabalhado no projeto de uma fonte de radiação síncrotron de terceira geração, o Sirius. Ele será construído ao lado do LNLS. A previsão de inauguração é para 2016. O novo acelerador síncrotron Sirius é apontado como um dos maiores projetos da ciência brasileira. Mas vale a pena investir nesse projeto em tempos de crise para laboratórios fora do país? De acordo com a Estratégia Nacional de Ciência, Tecnologia e Inovação (Encti), plano de ação publicado pelo Ministério de Ciência, Tecnologia e Inovação (MCTI), em 2011, "o número de usuários de luz síncrotron nas fontes mantidas pelo DOE (Departament of Energy), dos Estados Unidos, cresceu 40\%, no ESRF (European Syncrotron Radiation Facility), o aumento foi de 30\% entre 2003 e 2008.
No Brasil, esse aumento foi ainda maior: entre 1997, quando a fonte entrou em operação, e 2009, o número de usuário saltou de 229 para 2320 , algo em torno de $800 \%$ ". A iniciativa de construir o Sirius, apoiada pelo MCTI, tem o intuito de fornecer à comunidade científica e tecnológica uma ferramenta para manter a competitividade brasileira em áreas estratégicas, como nanotecnologia, biotecnologia e materiais avançados.

\section{OUTROS ACELERADORES NO MUNDO}

Existem cerca de 50 fontes de luz síncrotron no mundo, 16 delas já são de terceira geração. Países como a Índia, China e Rússia, economicamente importantes para o Brasil, e também o Irã, possuem ou estão investindo em aceleradores síncrotron com uma potência maior que a do LNLS.

Ao mesmo tempo, alguns aceleradores estão em crise. Em setembro de 2011, o laboratório norte-americano Fermilab encerrou as atividades com o acelerador Tevatron - o maior colisor próton-antipróton do mundo - por conta de dificuldades para obter financiamento. $\mathrm{Na}$ época em que foi construído, o Tevatron teve um custo de US\$ 120 milhóes (265 milhôes atualmente).

Em alguns aceleradores de partículas promovem-se colisōes para estudar o chuveiro de partículas que delas resultam. Esse é o caso do LHC (sigla para Large Hadron Collider), o maior acelerador de partículas do mundo, que fica no laboratório Cern, em Genebra, Suíça. Os aceleradores síncrotron são um tipo de acelerador de partículas em que há um campo magnético que orienta o feixe de partículas dentro de um circuito fechado. Uma fonte de luz síncrotron é uma combinação de diferentes tipos de aceleradores de elétrons, incluindo um anel de armazenamento no qual a radiação eletromagnética é gerada. A radiação é então usada em várias estaçôes experimentais localizadas em diferentes linhas de luz.

LNLS VERSUS SIRIUS Mas em que o Sirius difere do LNLS? Basicamente, a energia do feixe de elétrons do Sirius será maior, comparável a outros grandes aceleradores síncrotron no mundo. Enquanto o LNLS tem uma energia de feixe de $1.37 \mathrm{GeV}$, baixo brilho e um anel cujo diâmetro é de $93.2 \mathrm{~m}$, o Sirius terá três $\mathrm{GeV}$, com alto brilho e um diâmetro de 518.2 $\mathrm{m}$. E o que isso significa na prática para os pesquisadores brasileiros? Para o professor da Universidade Federal de Minas Gerais (UFMG), Lucas Bleicher, que está, atualmente, desenvolvendo seu trabalho em cristalografia de proteínas, fora do país, o Sirius vai diminuir a necessidade de fazer medidas no exterior. Bleicher teve que recorrer a outros aceleradores, como o de Brookhaven, nos Estados Unidos, porque o 

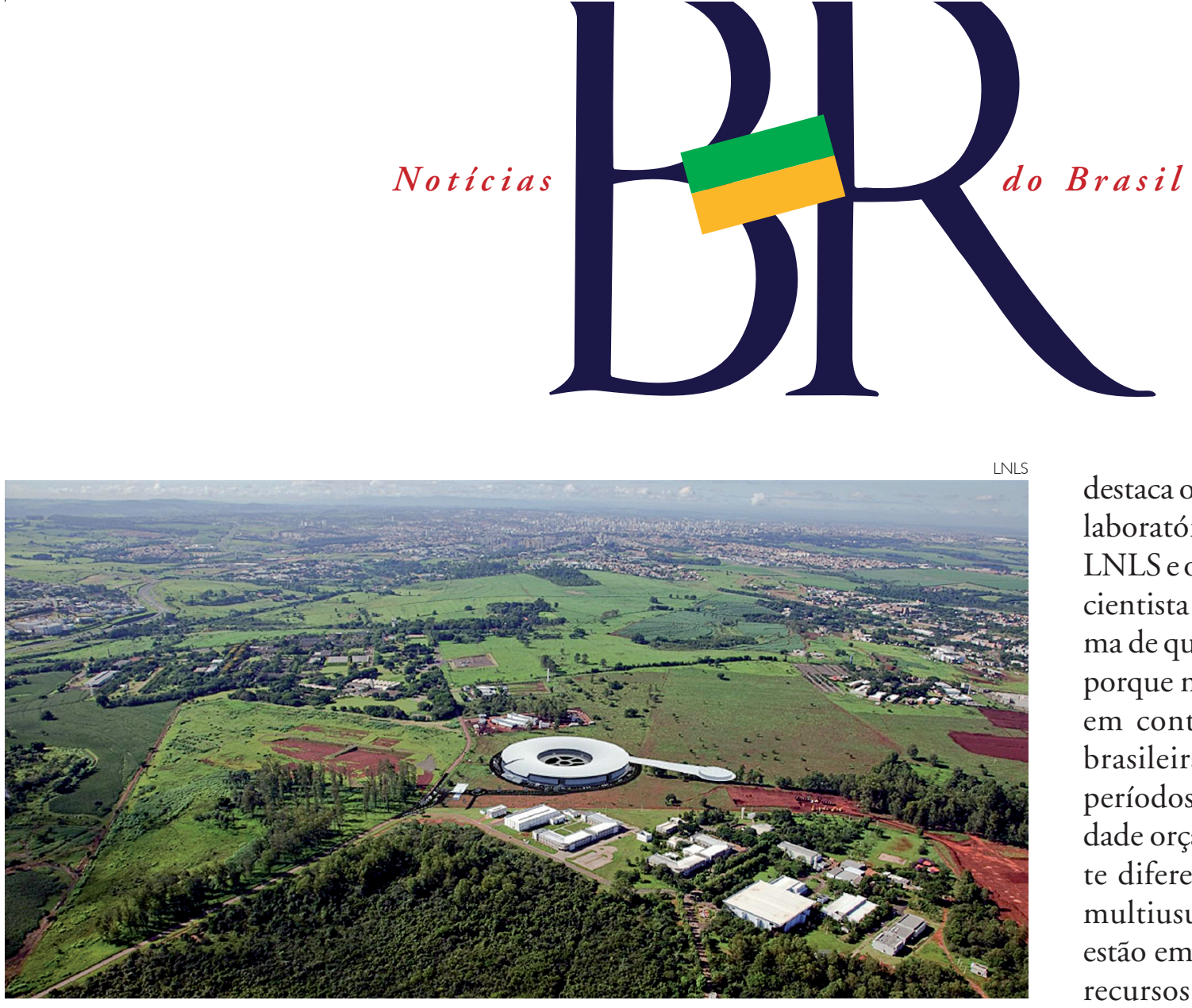

Localização do prédio do Sirius no campus do CNPEM, onde também estão o LNLS, o LNBio, o CTBE e o LNNano. A área total do Sirius é de $150.000 \mathrm{~m}^{2}$.

LNLS não tinha resolução suficiente para seu estudo sobre a estrutura de proteínas grandes. "Pelo menos no caso da cristalografia de proteínas (que tem duas linhas dedicadas no LNLS) isso não só deve acontecer, mas deve garantir que o tempo de feixe disponível seja suficiente para atender aos pesquisadores brasileiros. Quanto mais intenso é o feixe, menor é o tempo necessário para coletar os dados e assim a linha de luz pode atender mais gente".

A REALIDADE BRASILEIRA Na prática, conhecer a estrutura de proteínas é importante por que elas são muito usadas no desenvolvimento de novas drogas, e segundo Bleicher, boa parte das proteínas que se ligam às drogas são proteínas de membrana, que ao invés de ficarem livres na célula, se "enterram" na membrana celular. Isso torna a produção de cristais muito mais difícil. "Como cristais de grandes complexos e de proteínas de membrana comumente são menores e menos estáveis, dificilmente poderiam ser usados para determinação de estrutura na atual configuração da nossa fonte de luz síncrotron", diz ele. $\mathrm{Na}$ área de biologia estrutural, essas fontes de luz têm muitas perguntas a responder: como as células são capazes de fazer tarefas complicadas que envolvem a ação orquestrada de várias proteínas e sua interação com o DNA ou o RNA, como proteínas na membrana da célula são capazes de reconhecer sinais do exterior e transmiti-los para dentro da célula? Para Lucas Bleicher, há muitas vantagens no investimento em tecnologia de ponta para os aceleradores. Ele destaca o caráter "democrático" dos laboratórios multiusuários como o LNLS e o Sirius: "Quase todo jovem cientista brasileiro encontra o dilema de que tipo de pesquisa vai fazer, porque nem tudo é factível levando em conta a realidade econômica brasileira. Muitos passam longos períodos no exterior, onde a realidade orçamentária é completamente diferente. Com os laboratórios multiusuários, cientistas que hoje estão em universidades com menos recursos podem fazer boa ciência utilizando equipamentos mantidos especialmente para atender pesquisadores visitantes", finaliza.

\section{Victória Flório}

\section{SIRIUS EM NÚMEROS}

De acordo com o relatório de 2012, o orçamento total do projeto, de 2012 a 2017, ficará em R\$ 650 milhões, sendo que, no total, $65 \%$ serão destinados à construção do prédio e para a compra dos equipamentos das linhas de luz. Só no ano passado, teriam sido investidos quase R\$14 milhões. Ainda segundo o relatório, 29\% da verba será destinada à compra de equipamento importado, enquanto que $71 \%$, ou R\$ 461 milhões, vão para compras dentro do país. 